\title{
Analysis of Compliance with the Implementation of Medicines Standards by Pharmaceutical Staff at the Dr. Tadjuddin Chalid Central Public Hospital Makassar
}

\author{
Paramita Kurnia Wiguna ${ }^{1}$, Noer Bahry Noor $^{2}$, Hasnawati Amqam ${ }^{3}$ \\ ${ }^{1}$ Department of Hospital Management, Faculty of Public Health, Hasanuddin University, \\ Indonesia \\ ${ }^{2}$ Department of Hospital Management, Faculty of Public Health, Hasanuddin University, \\ Indonesia \\ ${ }^{3}$ Environmental Health Section, Faculty of Public Health, Hasanuddin University, Indonesia
}

\begin{abstract}
Medication errors are incidents that are detrimental to patients due to handling by health workers (human error) which is preventable. This study aims to analyze the application of drug administration standards by the pharmacy staff at Dr. Tadjuddin Chalid Makassar. This type of research is a combination research method (Mixed Methods) using the Sequential Explanatory model. The informants of this research were the pharmacy staff of the Central General Hospital (RSUP) dr. Tadjuddin Chalid Makassar. The results showed that the pharmacist's lack of accuracy was like a misreading of the doctor's writing. It is recommended that the hospital management conduct special training on the implementation of good drug administration standards and according to the SOP for drug administration, involving all health workers (doctors, nurses, pharmacists). Then conduct socialization of standard drug delivery SOPs and conduct regular evaluations (once a month) by including all officers related to drug administration.
\end{abstract}

Keywords: Drug Administration, Patient Safety, Hospital Pharmacy Installation

Received: October 26, 2020

Received in Revised: November 8, 2020

Accepted: November 10, 2020

\section{Introduction}

Medication errors are incidents that are detrimental to patients due to handling by health workers (human error) which is preventable. Medication errors can be classified into dispensing errors, prescribing errors, and Administration errors (Simamora et al., 2011). In general, the factors that most often influence Medication Error are individual factors, in the form of personal problems, inadequate knowledge of drugs, and errors in calculating drug doses (Mansouria et al., 2014).

Medication errors can occur in determining drugs and dosage regimens, the first being errors in prescribing; irrational prescriptions, inappropriate and ineffective prescriptions, overdose, under-dosage, in prescribing. The second is recipe writing: mistakes in interpreting the recipe. The third is manufacturing in formulations: wrong dosage, contaminants or wrong packaging. The fourth is formulation error: wrong drug, wrong formulation, wrong label. The fifth is the administration or taking of the drug: wrong dose, wrong route, wrong frequency, wrong duration (Aronson, 2009).

Patient safety incidents were found in Indonesia in 2011 Hospital Patient Safety Committee (KKPRS) reported 145 patient safety incidents. DKI Jakarta is a province that ranks the highest at $37.9 \%$, Central Java at $15.9 \%$, DI Yogyakarta at $13.8 \%$, East Java at $11.7 \%$, South Sumatra at $6.9 \%$, West Java at 2,8\%, Bali with 1.4\%, East Kalimantan with 0.69\%, and Aceh 
with $0.68 \%$. Other data on patient safety incidents in Indonesia show that near injury incidents (KNC) are more widely reported than adverse events (KTD). The reporting of near injury events was $47.6 \%$ while the adverse events were $46.2 \%$. In Indonesia, although publications about malpractice often appear in the mass media, official data on patient safety incidents are still rare. (Zulkani, 2018).

Data on the incidence of errors in administering drugs in Dr. Tadjuddin Chalid Makassar in the last 4 years, namely from 2016 as many as 12 cases $(0.032 \%$ of the total 30,271 sheets of recipes served, in 2017 as many as 13 cases $(0.028 \%$ of the total 45,221 recipes served), cases in 2018 as many as 11 cases ( $0.016 \%$ of the total 67,247 prescriptions served, and cases in 2019 were 8 cases $(0.010 \%$ of the total 74,428 prescriptions served). usage and incorrect writing of incomplete rules of use.

A similar study was conducted by Küng et al. (2013) at the University Hospital of Bern, Switzerland for a period of one month which reported 288 incidents of medication errors from a total of 24,617 doses of medication given to cardiovascular patients, of which $29 \%$ of the medication errors were prescribing errors, $13 \%$ transcription errors, and $58 \%$ in the form of administration errors. In addition, based on the results of a study in 2011-2013 conducted by the Pharmacology Department of Gajah Mada University, it was found that medication errors occurred in $97 \%$ of patients (Hartati et al., 2014).

Looking at the amount of data, it can be concluded that some pharmacy staff do not apply standards in administering drugs to patients. However, often in practice, the pharmacy staff is not maximal in carrying out the stages. Therefore, the researcher is interested in analyzing and comparing the compliance of the pharmacy staff in applying the drug delivery standards for the Central General Hospital (RSUP) dr. Tadjuddin Chalid Makassar. This study aims to analyze the application of drug administration standards by the pharmacy staff at Dr. Tadjuddin Chalid Makassar.

\section{Methods}

This research was conducted at Dr. Tadjuddin Chalid. This type of research is a combination research method (Mixed Methods) using a Sequential Explonatory research design model. The population used in this study was the Dr. Hospital prescription file. Tadjuddin Chalid. The sample of this research is 943 prescription drug files. The data collection technique or research instrument in this study is the main researcher because the researcher is the key instrument in this study. The research instruments used were observation sheets, interview sheets, and documents. The main instrument in this study is the researcher himself who is assisted and supported by other instruments. For qualitative methods, researchers used an instrument of the interview sheet and observation sheet.

In this study, qualitative data were analyzed qualitatively and quantitative data were analyzed descriptively. The two groups of data resulting from qualitative and quantitative analysis were further analyzed using the descriptive meta-analysis method (data analysis of quantitative and qualitative research results) in order to group, differentiate and find a relationship between one data and another, so that whether the two data reinforce, weaken or contradicting (Sugiyono, 2013).

\section{Results and Discussion}

Human resources are not sufficient in supporting compliance with the implementation of drug administration standards in hospitals. However, 5 informants stated that the available human resources were sufficient if needed at that time. This is based on informants 1 . 
"Actually, if that is the problem, there is less accuracy. Because the prescription should have been entered, we immediately checked first, and entered into had to double check. Sometimes it is usual to take the wrong drug. But I don't think so, because we always double check ".(P1, 42 Years)

"Drug prescribing error". (P2, 45 Years)

"Maybe more to the wrong drug, yeah?" (P3, 46 Years)

"Sometimes related to prescription problems" (P4, 40 Years)

"Wrong in drug administration". (P5, 41 Years)

"What often happens is wrong in prescribing or giving drugs to patients". (P6, 39 Years)

Based on the interview above, it is known that the compliance of human resources in the pharmaceutical installation is still not going well. This is due to a lack of accuracy where a double check should be done before the drug reaches the patient's hands, or it could also be caused by not being able to read the doctor's prescription.

From the scheme above, it can be seen that the cause of drug administration problems occurs because human resources in the pharmaceutical installation do not cooperate well. Both from fellow pharmacists and pharmacists to doctors.

"We search quickly, that's why every patient usually asks for his telephone number. That day we looked for the number and we went to ". (P1, 42 Years)

"We are looking for what is the source of the problem, we read the report. If necessary, we will socialize it again regarding the problem". (P2, 45 Years)

"We double-check again if something goes wrong". (P3, 46 Years)

"Judging from the patient's medical record, whether the patient is correct or not". (P4, 40 Years)

"We double-check again, we look at the cppt report or patient medical records related to personal data" (P5, 41 Years)

"We re-coordinate with those concerned such as nurses or doctors". (P6, 39 Years)

Based on the interview above, it is known that the related human resources coordinate with each other in handling problems. This is due to the creation of a solid working group, where they are accustomed to working together because of the demands every day to meet and the support of a harmonious work environment that encourages them to handle problems together to achieve the goals of a good hospital vision and mission.

"Of course they do follow up after the socialization, such as making reports after observations". (P1, 42 Years)

"Use data effectively and focus on program benchmarks for socialization materials. As well as coordination with the medical committee when evaluating the application of clinical practice guidelines and evaluating the performance of doctors using quality indicators. (P2, 45 Years)

"Sometimes the committee team comes down and carries out monitoring". (P3, 46 Years)

"Do socialization, but rarely". (P4, 40 Years)

"Training and socialization every six months" (P5, 41 Years) 
"Sometimes they do Ji Controlling". (P6, 39 Years)

Based on the interview above, it is known that the role of the patient safety committee team in the socialization of patient safety goals is very good, seen from the direct descent into the room for monitoring and making observation reports.

"Of course you have to be ready, starting from completing all forms of incident reports and proof of checklist forms". (P1, 42 Years)

"All incident reports must be ready, where the root of the problem is". (P2, 45 Years)

"Must be ready, reports must always exist". (P3, 46 Years)

"In every service unit that includes pharmacists in it must have availability on drug information sources". (P4, 40 Years)

"Must be ready, because we also always carry out reports of drug use errors in accordance with statutory regulations. Judging from the evidence of reporting medication errors according to statutory regulations ". (P5, 41 Years)

"We are always ready because the organization of pharmaceutical services and drug use must be carried out in accordance with the standards and laws and regulations". (P6, 39 Years)

Based on the interview above, the pharmacy Dr. Tajuddin Chalid is ready to face the audit. This happens because the system for recording reports both at the Hospital Pharmacy Installation (IFRS) and at each post or Hospital Management (TKRS) is always complete and filled, and they always carry out services according to the standards set by the hospital.

Based on the results of quantitative data that have been obtained, the exact identity of the patient in administering the drug at the Hospital Pharmacy Installation of the Central General Hospital (RSUP) Dr. Tajuddin Chalid, especially in paying attention to the name of the patient, only 28 out of 35 respondents $(80 \%)$, then did double-check at the time of drug delivery only 28 out of 35 respondents (80\%) did it. This is in line with Mahfudhah's (2018) research, it was found that nurses re-checked the drug label by checking the order of drugs prescribed by doctors before they were given to patients. This study is in line with research conducted by Sandramustika (2008) where the results of distributing questionnaires showed that 29 respondents $(96.67 \%)$ checked the name on the drug label before giving the injection to the patient to avoid the occurrence of injection errors, in addition to checking the shape. drug ampoules/vials (66.7\%) and the color of the liquid/drug to be given to the client $(53.3 \%)$ and checking the expiration of the drug. It is based on accreditation standards that the organization must assign clinical staff who are competent and authorized to administer drugs. Must ensure that the drug administration process includes a process of verifying whether the drug to be given is in accordance with the drug's prescription / request and that there are regulations made regarding the drugs that are taken by patients to the hospital for their own use. Compliance is something that can develop a routine (habit) that can help in following certain rules. Compliance occurs when the rules are followed correctly to form the expected behavior of a person (Lisnadiyanti \& Yuliasari 2016).

A prescription is a written and electronic request from a doctor to a pharmacist who manages a pharmacy to prepare and/or make, dispense, and deliver drugs to patients. The recipe must be written clearly and completely. Prescription services start from receiving, checking availability, reviewing prescriptions, preparing pharmaceutical preparations and medical supplies including drug compounding, checking, submitting accompanied by providing information. At each stage of the Prescription service flow, efforts are made to prevent medication errors. Activities to analyze the existence of drug-related problems, if problems 
are found related to drugs, consult the doctor who writes the prescription. Pharmacy personnel must conduct a prescription review according to administrative requirements, pharmaceutical requirements, and clinical requirements for both inpatients and outpatients.

Based on the research results presented, the following is a discussion regarding HR variables. Human resources are executing personnel who are sufficiently numbered and have the necessary capabilities and skills in implementing the implementation of established policies and programs. According to Azwar in his book introduction to health administration, human resources in an organization are very important because the goals of the organization are achieved or not, basically determined by human resources, namely humans and/or people who will carry out the organization's activities.

In addition, read the drug label to make sure that the method of administration is listed on the drug packaging (Potter \& Perry, 2005). According to the results of observations made by researchers, nurses checked or reread the suitability of the types of drugs with the route of drug administration listed on the prescription as recommended by the doctor before administering the drug (Mahfudhah \& Mayasari, 2018).

Based on the results of research that has been done, that socialization is carried out during shift changes and at the time of accreditation which aims to share information between pharmacists during shift exchanges. This is in line with Saud's (2019) study of pharmacy educators trying to correct the problem of inconsistent socialization through the extension and change of the experiential learning portion of the curriculum. Studies conducted on the professionalism of students as they progressed through school, clerkship, and initial work experience, did not show an increase or even a decrease in their social and work attitudes. Through medical records, pharmacists can also find out or fill in the patient's medical history information which will certainly be useful if there is a follow-up examination. The doctor's initial in the prescription is evidence that what is written in the prescription is valid (Susanti, 2013).

Periodic and continuous training and strengthening of how to correctly identify patients which contains the concept of nursing care theory, correct steps for administering medication, procedures for applying the existing Standard Operating Procedure for Patient Identification procedures. Developing a nurse compliance supervision system to identify patients in drug administration in the form of making special supervision SOPs, developing supervision formats and schedules, as well as socializing the supervision program to be carried out. Education and Training is an activity to develop human resources for Hospital Pharmacy Installation to increase their potential and productivity optimally, as well as to conduct education and training for prospective pharmacists to gain insight, knowledge and skills in the field of hospital pharmacy (Ministry of Health, 2016).

Based on the research results above, the pharmacy Dr. Tajuddin Chalid is ready to face audits because of the reporting system both at IFRS to evaluate all activities in IFRS and in every post related to pharmaceutical installations based on the standards set by the hospital. This is in line with Safitri's research (2015) which explains that internal audits in pharmaceutical installations are carried out to evaluate all activities in the pharmacy installation at PHC Hospital Surabaya which are carried out at the end of each month.

To be able to meet all the demand for medicines to customers, the hospital must have a good supply management system. This can be seen by conducting an operational audit. Many companies that have been carrying out their operational activities for a long time have been forced to go out of business, one of the factors is that their inventory management does not run according to established standards. Therefore, it is necessary to have supervision and 
control over the management function, in this case inventory management, to ensure the effectiveness of the planning that has been implemented and evaluated. Operational audit is an evaluation activity to assess the efficiency and effectiveness of the company's operations which can be carried out by internal or external auditors by providing recommendations or suggestions to improve the weaknesses found to top management.

\section{Conclusion}

Based on the results of the study, the researchers formulated the following conclusions: the pharmacist's lack of accuracy was like misreading due to unclear doctor's writing. Therefore it is necessary to double-check when the drug is given to patients. It is hoped that the hospital will hold special training on the application of good drug delivery standards and according to the SOP for drug administration, involving all health workers (doctors, nurses, pharmacists). Then conduct socialization of standard drug delivery SOPs and conduct regular evaluations (once a month) by involving all officers related to drug administration.

\section{References}

Aronson, J. K. (2009). Medication errors: definitions and classification. British journal of clinical pharmacology, 67(6), 599-604.

Hartati, H., Lolok, N. H., Fudholi, A., \& Satibi, S. (2014). Analisis kejadian medication error pada pasien ICU. Jurnal Manajemen dan Pelayanan Farmasi (Journal of Management and Pharmacy Practice), 4(2), 125-132.

Küng, K., Carrel, T., Wittwer, B., Engberg, S., Zimmermann, N., \& Schwendimann, R. (2013). Medication errors in a swiss cardiovascular surgery department: a crosssectional study based on a novel medication error report method. Nursing research and practice, 2013.

Lisnadiyanti, L., \& Yuliasari, S. (2016). Tingkat Pengetahuan Perawat Terhadap Kepatuhan Perawat Dalam Penerapan Standard Operating Procedure (Sop) Safe Handling Pada Pemberian Obat Sitotoksik. Jurnal Impuls Universitas Binawan, 2(1), 46-51.

Mahfudhah, A. N. (2018). Pemberian obat oleh perawat diruang rawat inap Rumah Sakit Umum Kota Banda Aceh. Jurnal Ilmiah Mahasiswa Fakultas Keperawatan, 3(4).

Mansouri, A., Ahmadvand, A., Hadjibabaie, M., Javadi, M., Khoee, S. H., Dastan, F., \& Gholami, K. (2014). A review of medication errors in iran: sources, underreporting reasons and preventive measures. Iranian journal of pharmaceutical research: $I J P R, 13(1), 3$.

Ministry of Health. (2016). Farmasi RS dan Klinik. In Farmasi RS dan Klinik (pp. 1-180). Kementerian Kesehatan Republik Indonesia. http://bppsdmk.kemkes.go.id/pusdiksdmk/wp-content/uploads/2017/08/FArmasiRS-dan-Klinik-Komprehensif.pdf

Safitri, H. M. (2015). Analisis Pengendalian Intern Atas Pelaksanaan Prosedur Persediaan Obat-obatan pada Rumah Sakit PHC Surabaya.E-Journal Akuntansi" EQUITY", 1(2).

Saud, A. (2019). Farmasi Sosial dan Administratif. Jurnal Farmasi Galenika (Galenika Journal of Pharmacy)(e-Journal), 5(1), 49-64.

Simamora, S. (2011). Peran Tenaga Teknis Kefarmasian Dalam Menurunkan Angka Kejadian Medication Error. Jurnal Manajemen Pelayanan Kesehatan, 14(04).

Sugiyono (2013). Memahami Penelitian Kualitatif. Bandung: Alfabeta. 
Susanti, I. (2013). Identifikasi Medication Error pada fase Prescribing, Transcribing, dan Dispensing di Depo Farmasi Rawat Inap Penyakit Dalam Gedung Teratai, Isntalasi Farmasi RSUP Fatmawati Periode 2013. Fakultas Kedokteran dan Ilmu Kesehatan, Jakarta: Universitas Islam Negeri Syarif Hidayatullah.

Zulkani, M. (2018). Budaya Keselamatan Pasien dalam Insiden KTD dan KNC Di Instalasi Laboratorium RSUD INCHE ABDOEL MOEIS SAMARINDA Tahun 2017. Thesis. Program PascaSarjana Fakultas Kesehatan Masyarakat Universitas Hasanuddin. 